\title{
Editorial
}

\section{Solar PV/Thermal Research}

\author{
Xudong Zhao, ${ }^{1}$ Clito Afonso, ${ }^{2}$ and Jie $\mathrm{Ji}^{3}$ \\ ${ }^{1}$ School of Engineering, Faculty of Science and Engineering, University of Hull, Yorkshire, UK \\ ${ }^{2}$ Centre of Innovation on New and Renewable Energies, Institute of Mechanical Engineering and Industrial Management, \\ University of Porto, Rua Dr. Roberto Frias, 4200-465 Porto, Portugal \\ ${ }^{3}$ School of Engineering and Science, University of Science and Technology of China, Hefei, China
}

Correspondence should be addressed to Xudong Zhao; xudong.zhao@hull.ac.uk

Received 26 January 2016; Accepted 2 February 2016

Copyright (C) 2016 Xudong Zhao et al. This is an open access article distributed under the Creative Commons Attribution License, which permits unrestricted use, distribution, and reproduction in any medium, provided the original work is properly cited.

This special issue is now ready for publication under the joint effort of the editorial board of this journal and the abovenamed special editors. The special issue contains the original research articles and review articles in relation to solar PV, solar thermal, and combined PV/thermal, addressing various aspects of the topics including theory, methodology and computer simulation, innovative materials, system configurations, energy, and socioeconomic performance analysis, as well as application case studies. We received a total of 30 manuscripts, of which 15 were selected for publication through the strict experts' peer reviews. The papers to be published in the special issue are "Application of a Noncarboxylated Dye Compound in a Dye-Sensitized Solar Cell Containing a Cyclodextrin Layer"; "Method to Calculate the Electricity Generated by a Photovoltaic Cell, Based on Its Mathematical Model Simulations in MATLAB"; "Study on Concentrating Characteristics of a Solar Parabolic Dish Concentrator within High Radiation Flux"; "Electrical and Thermal Performance Analysis for a Highly Concentrating Photovoltaic/ Thermal System"; "Sensitive Analysis for the Efficiency of a Parabolic Trough Solar Collector Based on Orthogonal Experiment"; "Competitiveness Level of Photovoltaic Solar Systems in Ouagadougou (Burkina Faso): Study Based on the Domestic Electric Meters Calibration"; "Safety Analysis of Solar Module under Partial Shading"; "Design and Implementation of Automatic Wheat Mower Based on Smart Sensor Fed by a Photovoltaic"; "Price-Efficiency Relationship for Photovoltaic Systems on a Global Basis"; "Technique for Outdoor Test on Concentrating Photovoltaic Cells"; "Behavior of Photovoltaic System during Solar Eclipse in Prague"; "PID Testing Method Suitable for Process Control of
Solar Cells Mass Production"; "Glazed PVT Collector with Polysiloxane Encapsulation of PV Cells: Performance and Economic Analysis"; "Experimental Investigation of the Effects of Partial Shading on Photovoltaic Cells' Electrical Parameters"; "Solar Thermal System Evaluation in China."

We believe the issue can showcase the latest technology development and excellent academic standard in this uprising subject, which has enormous market perspectives in the next decades. We would like to take this opportunity to thank all the authors who are interested in publishing their articles in this special issue. Our specific thanks will be to the editorial board members of this journal; without their help and contribution, this issue will never be concluded in such a short duration.
Xudong Zhao Clito Afonso Jie Ji 

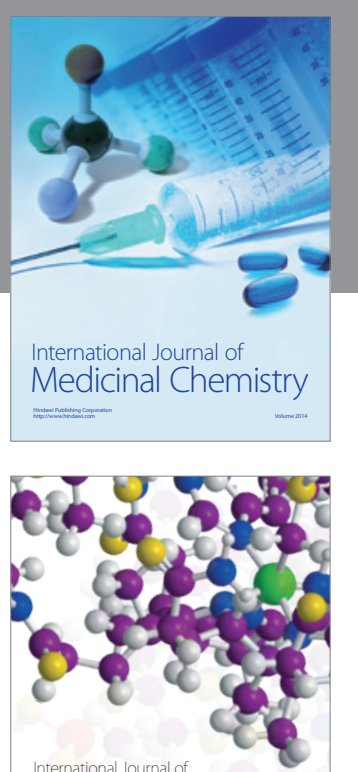

Carbohydrate Chemistry

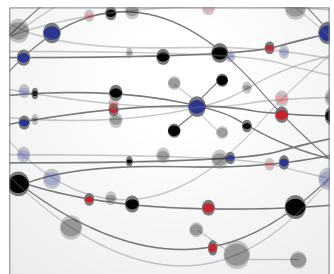

The Scientific World Journal
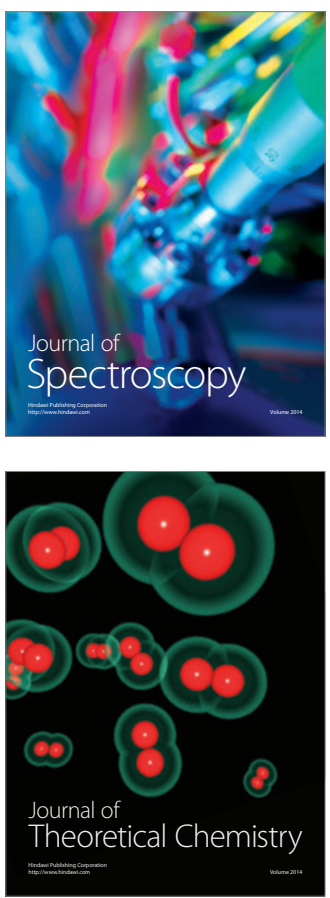
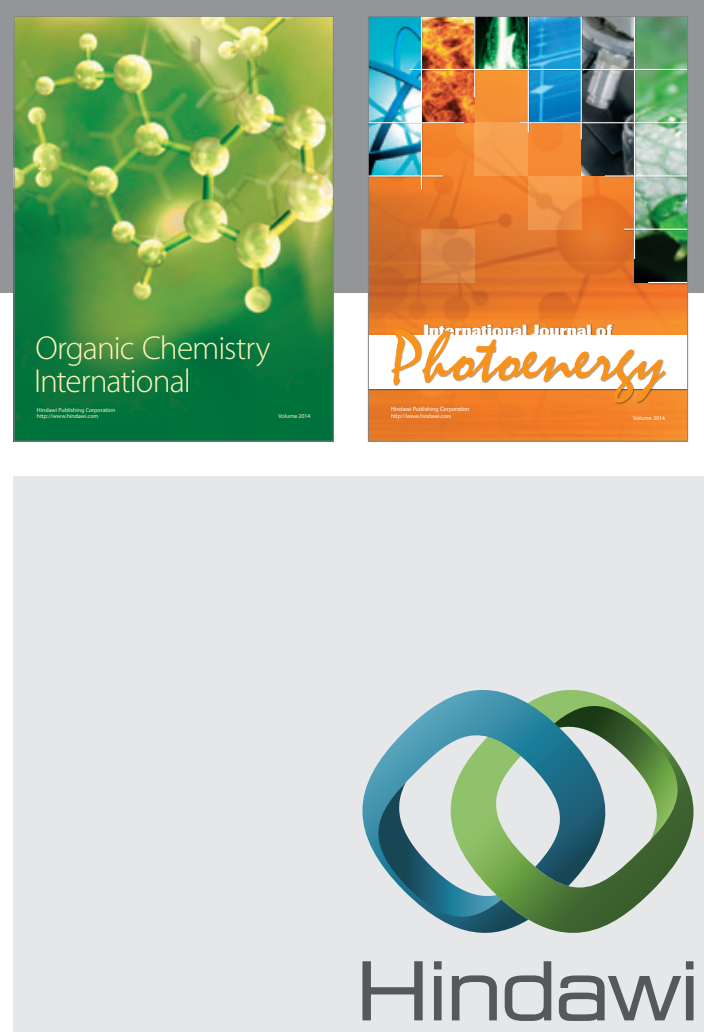

Submit your manuscripts at

http://www.hindawi.com

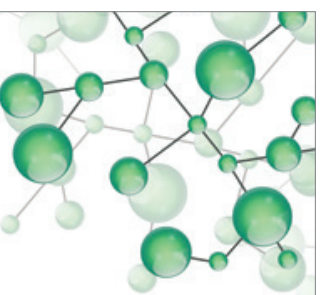

International Journal of

Inorganic Chemistry

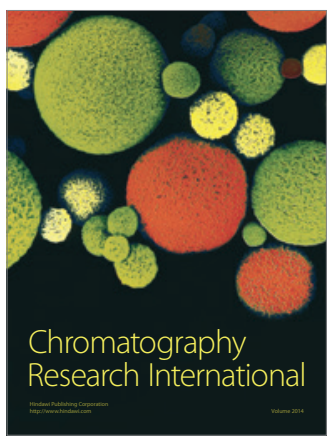

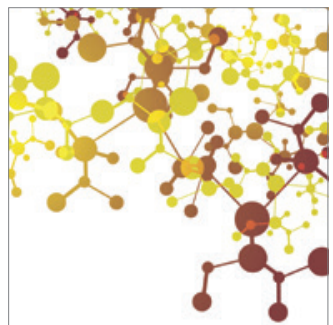

Applied Chemistry
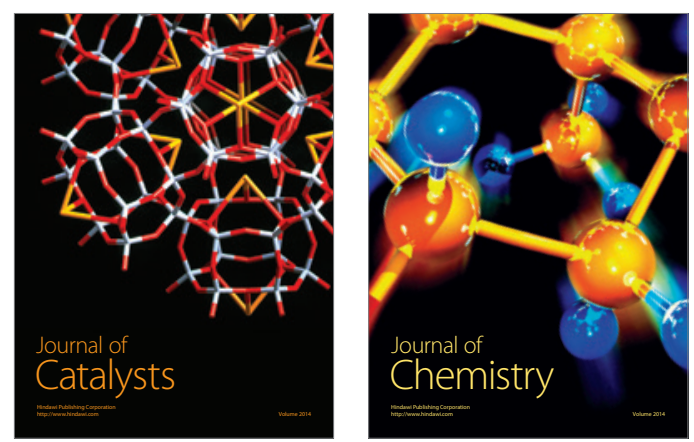
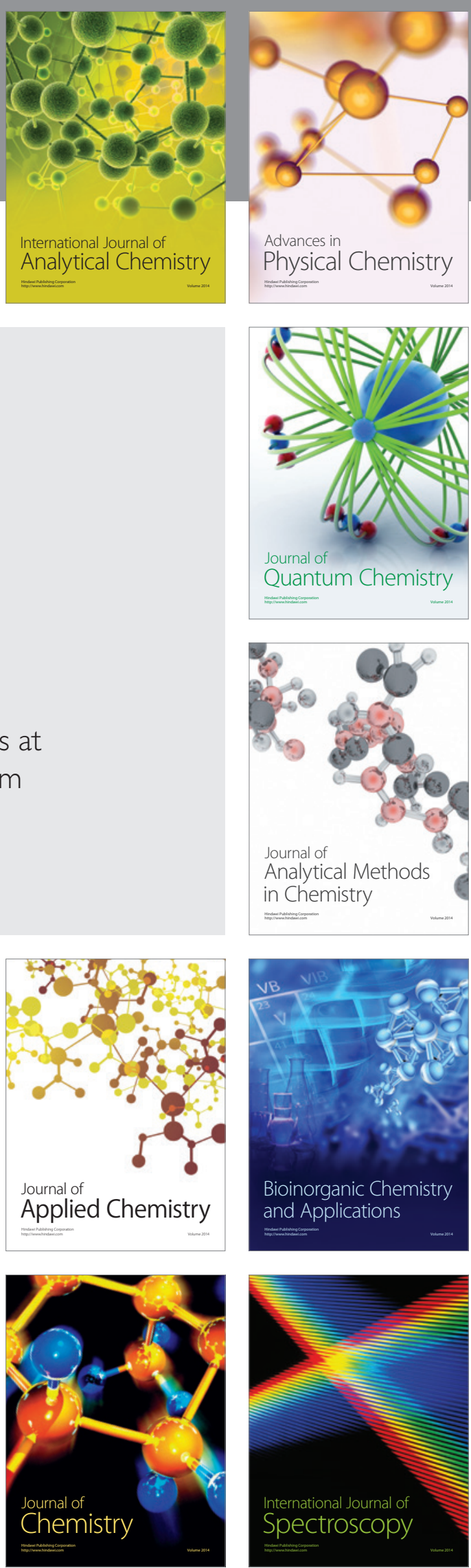